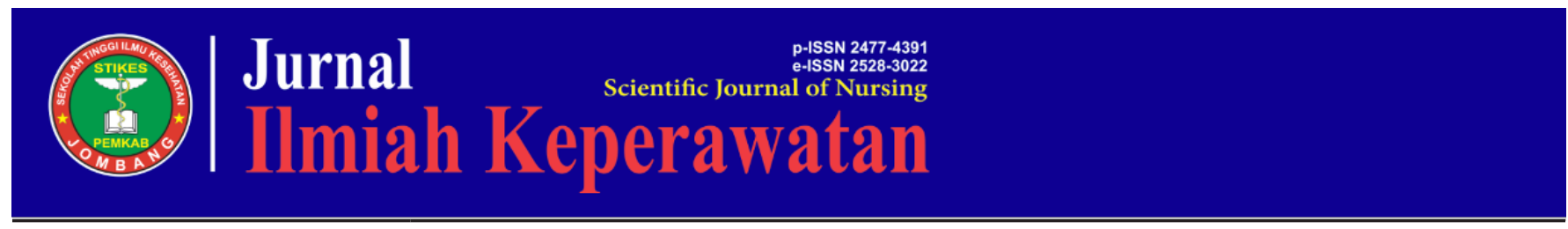

\title{
HUBUNGAN FATIGUE TERHADAP KUALITAS HIDUP PASIEN HEMODIALISA
}

\section{Gina Nurdina ${ }^{1}$, Dian Anggraini ${ }^{2}$}

1. Sekolah Tinggi Ilmu Keperawatan PPNI Jawa Barat

2. Sekolah Tinggi Ilmu Keperawatan PPNI Jawa Barat

\section{Riwayat artikel}

Diajukan: 07 Juli 2021

Diterima: 20 Juli 2021

\section{Email Korespondensi:} ghina.nurdina@gmail.com

\section{Kata Kunci:}

Fatigue, Quality Of Life, Hemodialysis

\begin{abstract}
Background: Hemodialysis helps increase the life expectancy of patients with chronic kidney disease, but patients also often report problems from the treatment, one of which is fatigue which is the most common symptom of hemodialysis patients and is often associated with quality of life problems.

Objective: To determine the relationship between fatigue and quality of life of hemodialysis patients.

Methods: The research design used is a correlational study with a cross-sectional approach. The population of this study were patients who underwent hemodialysis in various Hemodialysis Clinics in Bandung City with consecutive sampling technique. The instruments used in this study were the Fatigue Severity Scale (FSS) and Kidney Disease Quality of Life Short Form 36 (KDQoL-SF36). Univariate analysis using frequency distribution. Bivariate analysis was performed using the Pearson correlation test.

Results: From 34 respondents, most of the patients experienced fatigue with an average fatigue level of 41.18 ( $\mathrm{SD}=17.11)$. About $41 \%$ of respondents had high fatigue scores $(45<\mathrm{FAS}<=63)$. The mean KDQoL-SF36 score on the symptom/ problem list aspect is 66.02 ( $\mathrm{SD}=9.06$ ), the kidney disease effect aspect is 43.70 $(\mathrm{SD}=10.68)$, the burden aspect of kidney disease is 12.13 ( $\mathrm{SD}=5.94)$, the physical health component aspect is $35.79(\mathrm{SD}=6.58)$ and mental health component aspects $45.51(\mathrm{SD}=7.82)$. There is a relationship between fatigue with aspects of the burden of kidney disease and physical health component as seen from the $\mathrm{p}$ value $<0.05$ with a correlation coefficient of $(-0.491)$ and $(-0.515)$.
\end{abstract}

Conclusion: The higher the fatigue score, the lower the quality of life aspect score. 


\section{PENDAHULUAN}

Hemodialisis (HD) adalah salah satu terapi pengganti ginjal untuk pasien dengan penyakit ginjal kronis stadium akhir yang banyak digunakan. Berdasarkan data Indonesian Renal Resgistry (2018), jumlah pasien yang aktif menjalani HD di Indonesia sebanyak 198.575 orang dan angka tertinggi berada di Jawa Barat dengan jumlah pasien 48.599 orang dengan penambahan pasien baru sebanyak 37\% dari tahun 2017 sampai 2018. Angka tersebut akan terus meningkat setiap tahunnya.

Perawatan HD membantu meningkatkan harapan hidup pasien penyakit ginjal kronis, namun pasien juga sering melaporkan masalah dari pengobatan tersebut. Fatigue atau kelelahan adalah salah satu gejala paling umum dari pasien HD dan dikaitkan dengan kualitas hidup (Georgios et al, 2015). Konsep kelelahan ini tidak jelas sehingga sulit untuk didefinisikan dan dinilai secara kualitatif dan secara kuantitatif. Biasanya, istilah "kelelahan" mencakup beberapa komponen, seperti berkurangnya fungsi fisik dan mental, penurunan energi dan kinerja lebih rendah dari yang diharapkan (Eğlence, R., Karataş, N., \& Taşci, S., 2013)

Prevalensi pasien HD yang mengalami fatigue sebanyak 60-97\%. Lebih dari 70\% dari pasien dialisis mengalami fatigue berat (Artom et al, 2014). Tingkat kelelahan pada pasien HD adalah salah satu yang tertinggi dari semua pasien penyakit kronis termasuk mereka yang mengalami depresi berat, pasien kanker yang menjalani kemoterapi, dan pasien lupus. Kelelahan pada pasien HD cukup mirip dengan mereka yang menderita sindrom kelelahan kronis, karena mereka memiliki kelemahan umum, penurunan toleransi dalam olahraga, dan gangguan tidur. Gejala-gejala ini menyebabkan rasa kekurangan energi (Georgios et al, 2015).

Fatigue yang terjadi pada pasien HD juga akan mempengaruhi proses berfikir dan konsentrasi serta gangguan dalam hubungan sosial. Kondisi tersebut mungkin akan mempengaruhi kualitas hidup pasien HD (Fatayi, 2008). Selain fatigue, pasien HD juga mengalami komplikasi seiring dengan penyakit yang mereka derita dimana komplikasi tersebut mungkin berakibat pada menurunnya kualitas hidup klien. pasien gagal ginjal yang mejalani terapi hemodialisa diketahui rata-rata kualitas hidup berada pada kategori rendah (Wyld, Morton, Hayen, Howard \& Webster, 2012). Banyak faktor yang berkontribusi terhadap kualitas hidup yang lebih baik pada pasien HD, termasuk usia yang lebih muda, tingkat pendidikan yang lebih tinggi, kesadaran tentang masalah kesehatan mereka, kepatuhan dengan diet yang diusulkan, rekomendasi terapi, hubungan baik dengan staf perawatan kesehatan dan pasien lain, memiliki dukungan sosial yang baik, durasi dialisis yang singkat, ketidakhadiran dan tanpa penyerta diabetes mellitus (DM), kalsium serum yang lebih rendah, aliran darah yang lebih tinggi, dan asupan protein. Kualitas hidup pasien harus menjadi fokus selama pengobatan HD dan membantu pasien dalam menerima penyakitnya (Işı1k Ulusoy, S., \& Kal, Ö, 2020). Beberapa penelitian telah menyoroti pentingnya peran penerimaan pasien terhadap penyakit mereka sebagai faktor dalam kualitas hidup mereka, depresi dan kecemasan, atau kualitas hidup yang berhubungan dengan kesehatan fisik dan mental pada pasien. Peneliti sebelumnya menyatakan bahwa terdapat korelasi yang konsisten antara kelelahan dan empat domain kualitas hidup dalam WHOQOL BREF yaitu domain kesehatan fisik, psikologis, sosial dan lingkungan (Natashia, Irawati \& Hidayat, 2020). Namun perbedaan penelitian ini adalah jenis kuesioner kualitas hidup yang akan digunakannya yaitu Kidney Disease Quality of Life Short Form 36 (KDQOL SF36). Kuesioner tersebut diperuntukan mengukur kualitas hidup apsda pasien dengan penyakit ginjal. Sehingga penelitian lebih lanjut diperlukan untuk mengetahui hubungan antara fatigue dengan berbagai dimensi kualitas hidup dalam Kidney Disease Quality of Life Short Form 36 seperti daftar gejala/masalah, efek penyakit ginjal, beban penyakit ginjal, komponen kesehatan fisik dan komponen kesehatan mental.. Maka dari itu tujuan dari penelitian ini adalah untuk mengetahui hubungan tingkat fatigue terhadap kualitas hidup pada pasien hemodialisis.

\section{METODE}

Jenis penelitian yang digunakan adalah studi korelasional dengan pendekatan cross-sectional. Variabel dependent adalah kualitas hidup dan variabel independent adalah fatigue. 


\section{Populasi dan Sampel Penelitian}

Populasi penelitian ini adalah pasien yang menjalani hemodialisa di beberapa klinik hemodialisa di Kota Bandung. Pasien tersebut tergabung dalam Komunitas Pasien Cuci Darah Indonesia Jawa Barat (KCPDI Jawa Barat). Kriteria inklusi yaitu usia $\geq 20$ tahun, pengobatan hemodialisis selama $\geq 3$ bulan dan kesadaran compos mentis. Kriteria ekslusinya yaitu disfungsi kognitif atau keterbelakangan mental. Tehnik pengambilan sampel menggunakan consecutive sampling. Jumlah sampel dihitung menggunakan G-

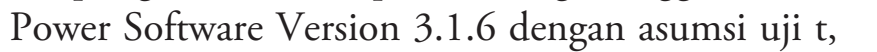
$=0.05$, effect size $=0.5$, power level $=0.80$. Sehingga total sampel yang akan direkrut adalah 34 responden.

\section{Alat Pengumpulan Data}

Alat pengumpulan data yang digunakan dalam penelitian ini adalah sebagai berikut :

1. Kuesioner, digunakan untuk mengumpulkan data terkait karakteristik responden yaitu usia, jenis kelamin, pekerjaan dan lama menjalani hemodialisa.

2. Instrumen the Fatigue Severity Scale untuk mengukur tingkat Fatigue. Kuesioner ini terdiri dari sembilan pernyataan yang mewakili tingkat kelelahan responden. Skor tertinggi adalah 63 dan terendahnya 9. Hasil uji validitas didapatkan nilai $r$ tabel (uji 2 sisi) pada signifikansi $5 \%$ dengan $\mathrm{n}=32$, didapat sebesar 0,349 . Nilai korelasi ( $\mathrm{r}$ hasil) seluruh pertanyaan 1 hingga $9>\mathrm{r}$ tabel $(0,349)$ dan nilai Alpha sebesar 0,88 (Butarbutar, 2014)

3. Kualitas hidup diukur dengan instrumen Kidney Disease Quality of Life Short Form 36 (KDQoL-SF36). Kuesioner ini terdiri dari 36 butir pertanyaan dengan 5 aspek yaitu daftar gejala/masalah, efek penyakit ginjal, beban penyakit ginjal, komponen kesehatan fisik dan komponen kesehatan mental. Hasil uji validitas instrumen ini menunjukkan korelasi bermakna $(\mathrm{p}<0,001)$ sedangkan nilai reliabilitas konsistensi internal dapat diterima dengan nilai Cronbach Alpha $\geq 0,7$ untuk seluruh skala (Supriyadi, 2019).

\section{Prosedur Pengumpulan data}

Penelitian diawali dengan peneliti mengurus segala perizinan yang diperlukan, setelah mendapatkan perizinan, peneliti akan mengidentifikasi responden penelitian. Peneliti bergabung ke dalam Grup
Whatsapp KCPDI Jabar. Peneliti menjelaskan pada responden tentang tujuan dan manfaat penelitian dan meminta kesediaannya untuk menjadi responden, ketika klien bersedia menjadi responden, maka klien diminta untuk menyetujui informed consent dan masuk kedalam grup Whatsapp penelitian. Responden diminta mengisi kuesioner melalui link Google form yang peneliti berikan. Google form tersebut berikan kuesioner karakteristik responden, the Fatigue Severity Scale dan Kidney Disease Quality of Life Short Form 36 (KDQoL-SF36). Setelah itu peneliti mengumpulkan hasil pengkajian untuk selanjutnya dilakukan pengolahan data.

\section{Analisa data}

Analisa data mengguakan aplikasi IBM SPSS Statistik versi 24. Uji normalitas menggunakan KolmogorovSmirnov Test hasilnya semua variabel berdistribusi normal. Analisis bivariat untuk mengetahui korelasi antara fatigue dan kualitas hidup menggunakan pearson correlation. Signifikansi statistik didefinisikan sebagai nilai p kurang dari 0,05 .

\section{HASIL DAN PEMBAHASAN}

\section{HASIL}

Penelitian dilakukan pada pasien hemodialisa yang tergabung dalam KCPDI Jawa Barat. Pengumpulan data dilakukan pada bulan Mei 2021 dengan total sampel 34 responden. Hasil penelitian disajikan dalam bentuk tabel dan narasi yang didasarkan pada hasil analisis univariat dan bivariat sebagai berikut:

\section{Analisa Univariat}

Berdasarkan tabel 1 diatas menunjukkan rata-rata usia sebesar 38,38 (SD = 11.114). Jumlah jenis kelamin laki-laki dan perempuan sama yaitu 17 orang. Untuk riwayat pendidikan sebagian besar responden (64.7\%) lulusan SMA/sederajat dan lama menjalani hemodialisa rata-rata $3.41(\mathrm{SD}=0,925)$ terbanyak pada range $\geq 3$ tahun (61.8\%). Sedangkan sebanyak 19 responden $(55.8 \%)$ tidak bekerja. 
Tabel 1. Karakteristik Responden

\begin{tabular}{ll}
\hline Variabel & Total $\mathrm{n}(\%)$ \\
\hline $\begin{array}{l}\text { Usia (mean } \pm \text { SD) } \\
\text { Jenis Kelamin }\end{array}$ & $38.38 \pm 11.114$ \\
Laki-laki & \\
Perempuan & $17(50 \%)$ \\
Pendidikan & $17(50 \%)$ \\
SMP/Sederajat & \\
SMA/Sederajat & $6(17.6 \%)$ \\
Perguruan Tinggi & $22(64.7 \%)$ \\
Lama menjalani HD \\
(mean \pm SD) & $6(17.6 \%)$ \\
Range & \\
$<3$ tahun & $(3.41 \pm 0.925)$ \\
$\geq 3$ tahun & $13(38.3 \%)$ \\
Pekerjaan & $21(61.8 \%)$ \\
Bekerja & \\
Tidak bekerja & $15(44.2 \%)$ \\
\hline
\end{tabular}

Tabel 2. Distribusi Skor Fatigue Severity Scale

\begin{tabular}{lcc}
\hline & Frekuensi & Persen $(\%)$ \\
\hline $9<\mathrm{FAS}<=27$ & 8 & 24 \\
$27<\mathrm{FAS}<=45$ & 12 & 35 \\
$45<\mathrm{FAS}<=63$ & 14 & 41
\end{tabular}

Berdasarkan Tabel 2 menunjukan bahwa sebanyak $41 \%$ responden memiliki skor FAS diantara 45-63.

Tabel 3. Karakteristik fatigue dan kualitas hidup

\begin{tabular}{lcc}
\hline \multicolumn{1}{c}{ Variabel } & Mean \pm SD & Min-Max \\
\hline Fatigue & $41.18 \pm 17.11$ & $9-63$ \\
Kualitas hidup & & \\
Daftar gejala/masalah & $66.02 \pm 9.06$ & $50-85.42$ \\
Efek penyakit ginjal & $43.70 \pm 10.68$ & $28.13-65.63$ \\
Beban penyakit ginjal & $12.13 \pm 5.94$ & $6.25-25$ \\
Komponen Kesehatan & $35.7 \pm 6.58$ & $23.31-47.22$ \\
fisik & & \\
$\begin{array}{l}\text { Komponen Kesehatan } \\
\text { mental }\end{array}$ & $45.51 \pm 7.82$ & $29.75-60.18$ \\
\hline
\end{tabular}

Berdasarkan Tabel 3 menunjukkan bahwa rata-rata nilai fatigue sebesar $41.18(\mathrm{SD}=17.11)$. Semakin tinggi skornya maka tingkat kelelahanya semakin tinggi. Rerata skor KDQoL-SF36 tertinggi didapatkan untuk aspek daftar gejala/masalah (66.02 \pm 9.06$)$ dengan nilai terendah 50 dan tertinggi 85.42 sedangkan skor terendah yaitu aspek beban penyakit ginjal $(12.13 \pm 5.94)$ dengan nilai terendah 6.25 dan tertinggi 25 .

\section{Analisa Bivariat}

Tabel 4. Hubungan antara Fatigue dan Kualitas Hidup

\begin{tabular}{lcc}
\hline & \multicolumn{2}{c}{ Fatigue } \\
\hline \multicolumn{1}{c}{ Aspek Kualitas Hidup } & $\mathrm{p}$ value & $\mathrm{r}$ \\
\hline Daftar gejala/masalah & 0.073 & -0.312 \\
Efek penyakit ginjal & 0.025 & -0.383 \\
Beban penyakit ginjal & $0.003^{*}$ & -0.491 \\
Komponen Kesehatan fisik & $0.002^{*}$ & -0.515 \\
Komponen Kesehatan & 0.067 & -0.318 \\
mental & & \\
${ }^{*} p<0,05$ & &
\end{tabular}

Berdasarkan tabel 4. didapatkan hasil bahwa terdapat hubungan antara fatigue dengan aspek beban penyakit ginjal dan kesehatan fisik terlihat dari nilai $\mathrm{p}$ value $<0.05$ dengan nilai koefisien korelasi sebesar $(-0.491)$ dan $(-0.515)$ yang bermakna bahwa semakin tinggi skor fatigue maka semakin rendah skor aspek kualitas hidupnya.

\section{PEMBAHASAN}

Rerata usia responden dalam penenlitian ini adalah 38,38. Usia merupakan salah satu faktor yang mempengaruhi status kesehatan seseorang. Usia lebih dari 30 tahun mulai terjadinya proses degeneratif yang akan menyebabkan perubahan fisiologi dan bikomia pada tubuh, ginjal akan menurun fungsinya sekitar $1 \%$ setiap tahun (Natashia, Irawati \& Hidayat, 2020). Sebagian besar responden tidak bekerja $(55.8 \%)$ hal ini sejalan dengan penelitian lainya bahwa pasien yang menjalani hemodialisis menanggung beban ekonomi yang signifikan karena kehilangan pekerjaan, yang mungkin disebabkan oleh penyakit (Wang et al., 2015). Pasien hemodialisa yang menganggur dan tidak dapat bekerja, dikarenakan hambatan dari kondisi penyakit mereka dan disinsentif sosial (Kimmel, 2000).

Hasil penelitian menunjukan bahwa rata-rata skor fatigue sebesar $41.18 \quad(\mathrm{SD}=17.11)$. Sekitar $41 \%$ responden memiliki skor fatigue tinggi $(45<\mathrm{FAS}<=63)$. Skor fatigue berbanding positif terhadap tingkat kelelahan. Semakin tinggi skornya maka tingkat kelelahannya semakin tinggi. Sejalan dengan penelitian Kusniyati (2020) bahwa sebanyak $57,1 \%$ dari 105 pasien hemodialisa mengalami fatigue. Kelelahan yang dialami pasien HD dapat berhubungan dengan kondisi fisik, seperti anemia dan malnutrisi (Jhamb et al, 2011). Faktor lain, seperti usia yang lebih tua atau memiliki tingkat pendidikan yang lebih rendah, tingkat albumin yang 
lebih rendah, gangguan tidur, atau tingkat stres yang lebih tinggi dapat mempengaruhi tingkat kelelahan (Yang \& Lu, 2017). Fatigue pada pasien hemodialisa disebabkan oleh sindrome uremia. Sindrom uremia pada pasien hemodialisa mengakibatkan fatigue perifer. Fatigue perifer ini terjadi karena adanya gangguan sistem saraf perifer, disebabkan karena adanya uremik neuropati yang mengakibatkan adanya kerusakan sel saraf di daerah distal, sistemik, motorik, dan sensorik. Gangguan ini biasanya dapat terlihat didaerah ekstrimitas bawah dan atas. Manifestasi klinis kerusakan sel saraf perifer ini berupa kebas didaerah kaki, nyeri, ataksia, dan kelemahan. Kerusakan sel saraf perifer ini menunjukkan adanya keterlambatan konduksi saraf motorik dan potensial aksi sensorik yang diakibatkan karena adanya uremia dan tidak adekuatnya dialisa sehingga ureum tidak bisa dibuang (Daugirdas, et al, 2015; Davis \& Walsh, 2010).

Pasien yang menjalani hemodialisis menganggap kelelahan sebagai gejala yang melemahkan dan sulit ditangani (Jhamb et al., 2009). Kondisi tersebut dapat mempengarui status kesehatan fisik dan sosial dimana pasien HD yang mengalami fatigue dalam tingkat berat cenderung tidak dapat bekerja karena merasakan kelemahan fisik (Septiwi, 2010). Studi lain menemukan bahwa kelelahan memiliki dampak negatif pada kehidupan sehari-hari pasien, kualitas hidup, kondisi kardiovaskular, dan kelangsungan hidup (Bossola et al, 2011).

Hasil pengukuran kualitas hidup pasien menunjukan aspek daftar gejala/masalah berada pada rerat tertinggi $($ Mean=66.02) dibanding aspek lain. Berdasarkan daftar gejala di instrumen mayoritas menjawab "agak terganggu" atau "sama sekali tidak terganggu". Sejalan dengan penelitian yag dilakukan oleh Cohen et al (2019) dan Cervantes et al (2020) bahwa aspek daftar gejala/masalah memiliki nilai rerata yang lebih tinggi dari aspek yang lain. Hal ini memunculkan kemungkinan bahwa daftar gejala yang ditanyakan dalam instrumen mungkin perlu disegarkan untuk memperhitungkan perubahan dalam pengalaman dialisis yang sudah lama. Hasil penelitian ini responden sebagian besar sudah menjalani hemodialisa lebih dari tiga tahun sehingga pasien sudah beradaptasi dengan berbagai gejala. Namun berdasarkan temuan penelitian terdapat gejala-gejala yang cukup mengganggu yaitu kulit kering dan kulit gatal. Penelitian lain menyebutkan pasien hemodialisa mengalami keluhan gatal ringan dan berat namun tidak ada hubungan yang signifikan antara kejadian kulit keirng dan gatal dengan lama hemodialisa. Kulit kering diakibatkan karena uremia yang mempengaruhi perubahan pada maturasi korneosit dan penurunan kandungan air pada bagian epidermis kulit, penurunan volume pada atrofi kelenjar sebasea dan kelenjar keringat sehingga kulit menjadi kering dan gatal (Toruan, 2019)

Aspek beban panyakit ginjal dalam penelitian ini memiliki nilai rerata yang paling rendah.. Selain itu, hasil analisis bivariat menunjukkan bahwa fatigue mempunyai pengaruh terhadap kulitas hidup pada aspek beban penyakit ginjal ( $p$ value $<0.05$ ). Semakin tinggi tingkatan fatigue maka semakin rendah kulitas hidupnya. Berdasarkan butir pertanyaan pada instrumen mayoritas responden merasa penyakit ginjal ini terlalu banyak mengganggu kehidupannya. Sehingga pasien merasa frustasi dan menjadi beban bagi keluarganya. Hal tersebut sejalan dengan hasil penelitian kualitatif bahwa dampak fatigue begitu besar dirasakan oleh pasien HD. Sebagai konsekuensi dari fatigue, pasien HD mengalami keterbatasan partisipasi dalam hidup dan merasa tergantung dengan pengobatan. Mereka merasa tidak dipahami oleh orang lain dan gagal dalam memenuhi harapan. Hal tersebut mempengaruhi harga diri pasien terkait dengan perubahan peran, hubungan, identitas dan makna dalam hidup sehingga penyakit ginjal ini menjadi beban yang berat bagi mereka (Borg, 2021). Penelitian lain menyatakan pasien HD merasa bersalah karena harus begantung dan membebani pasangan atau anak-anaknya. Pasien HD yang memiliki anak mengira mereka mengecewakan anak-anaknya karena kehabisan energi untuk menghabiskan waktu bersama mereka. Sedangkan pasien HD yang menjadi pencari nafkah tidak mampu menghidupi keluarga dan menjadi beban keluarga.

Beban penyakit ginjal lainnya yaitu banyaknya waktu yang harus dihabiskan untuk pengobatan penyakit ginjal. Banyaknya waktu yang dihabiskan untuk melakukan sesi dialisis selama 3-4 jam dalam seminggu 3 kali membuat semua energi dan kekuatan mereka terkuras sehingga mengalami fatigue. Butuh waktu yang lama untuk kembali pulih setelah proses hemodialisa. Pasien ingin memulihkan energinya dengan beristirahat, tapi hal tersebut justru menghalangi mereka untuk melakukan aktifitas lainnya (Jacobson et al, 2019). Hal terseut juga dapat 
menjadi alasan mengapa fatigue memiliki hubungan terhadap aspek kuliatas hidup yaitu komponen kesehatan fisik.

Dalam penelitian ini juga didaptkan bahwa fatigue berhubungan dengan aspek komponen kesehatan fisik. Dalam studi kuantitatif Bai et al (2018) tentang kualitas hidup, menunjukkan bahwa vitalitas pasien, fungsi fisik, dan keterbatasan peran fisik mempengaruhi kualitas hidup mereka. Selain itu, pasien yang menerima hemodialisis menderita keterbatasan vitalitas yang serius sehingga mengalami kelelahan dan kekurangan energi yang konstan.

Berkenaan dengan efek kelelahan pada kualitas hidup, Jhamb et al. (2011) menemukan bahwa pasien yang menjalani hemodialisis dengan vitalitas rendah memiliki kualitas hidup yang secara signifikan lebih rendah dalam hal kesehatan mental, fungsi fisik, nyeri fisik, dan kualitas tidur. Sejalan dengan penelitian Georgios et al (2015) bahwa pasien dengan tingkat kelelahan yang rendah memiliki kualitas hidup yang lebih baik dibandingkan dengan mereka yang memiliki tingkat kelelahan yang tinggi. Mengingat beban gejala yang sehari-hari dialami oleh pasien yang menjalani HD seperti lemah, mual, kram, gatal, nyeri berkorelasi dengan tingkat kelelahan dengan subskala gejala. Dimensi gejala mempengaruhi kualitas hidup yang lebih positif bagi pasien yang mengalami tingkat kelelahan yang lebih rendah dibandingkan dengan mereka yang mengalami tingkat yang lebih tinggi kelelahan. Yu dan Petrini (2010) melakukan penelitian kualitatif kualitas hidup pada 16 pasien yang menjalani hemodialisis. Temuan menunjukkan bahwa ketidakstabilan emosional, tekanan psikologis, beban keuangan, kurangnya kesadaran penyakit, dan kurangnya dukungan sosial dapat mempengaruhi kualitas hidup pasien. Berdasarkan penelitianpenelitian tersebut dapat disimpulkan bahwa pasien yang menjalani pengobatan hemodialisis menderita kesehatan fisik yang buruk yang sejalan dengan penelitian ini.

Peneliti menyarankan kepada profesional kesehatan harus mengadopsi pendekatan yang komprehensif untuk mengkaji tingkat fatigue. Langkah pertama dalam mengatasi fatigue adalah mengenali gejala dan ukurannya (Georgios et al, 2015). Bimbingan tentang nutrisi, manajemen stres, manajemen tidur, latihan fisik, konservasi energi, dan membangun jaringan sosial dapat menjadi solusi untuk membantu pasien
HD mengendalikan fatigue dan masalah psikologis mereka, dan pada akhirnya, untuk meningkatkan kualitas hidup mereka (Smart \& Steele, 2011).

\section{KESIMPULAN}

Berdasarkan hasil penelitian ini didapatkan bahwa sebagian besar pasien mengalami fatigue dengan rerata tinkat fatigue $41.18(\mathrm{SD}=17.11)$. Sekitar $41 \%$ responden memiliki skor fatigue tinggi $(45<\mathrm{FAS}<=63)$. Rerata skor KDQoL-SF36 tertinggi didapatkan untuk aspek daftar gejala/masalah $(66.02 \pm 9.06)$ dan skor terendah untuk aspek beban penyakit ginjal $(12.13 \pm 5.94)$. Terdapat hubungan antara fatigue dengan aspek beban penyakit ginjal dan kesehatan fisik terlihat dari nilai $\mathrm{p}$ value $<0.05$ dengan nilai koefisien korelasi sebesar (-0.491) dan (-0.515) yang bermakna bahwa semakin tinggi skor fatigue maka semakin rendah skor aspek kualitas hidupnya.

Penelitian ini diharapkan dapat dijadikan referensi untuk penelitian selanjutnya. Sehingga dapat dilakukan penelitian lanjutan, seperti pentingnya dilakukan penelitian mengenai pengembangan intervensi untuk mengurangi fatigue dan meningkatkan kualitas hidup pasien hemodialisa.

\section{DAFTAR PUSTAKA}

Artom, M., et al, 2014, 'Fatigue in advanced kidney disease'. Kidney International, 86(3),1-9.

Bai, Y., Chang, Y., Chiou, C \& Lee, B, 2018, 'Mediating effects of fatigue on the relationships among sociodemographic characteristics, depression, and quality of life in patients receiving hemodialysis', Nurs Health Sci. 2018;1-8.

Borg, Ms \& Verdonk, Petra \& Jong-Camerik, Ms \& Abma, Tineke, 2021, How to relate to dialysis patients' fatigue - perspectives of dialysis nurses and renal health professionals: A qualitative study. International Journal of Nursing Studies. 117. 103884.

Butarbutar, D., Sudira, P., Astuti, \& Setyaningsih, I., 2014, Uji Reliabilitas dan Validitas Kuesioner Fatigue Severity Scale Versi Bahasa Indonesia Pada Dokter Residen Rumah Sakit Umum Pusat Dr. Sardjito, Pertemuan Ilmiah Regional XXVI.

Dokter Spesialis Saraf JOGLOSEMARMAS

Cervantes, et al, 2021, 'Patient-reported outcomes and experiences in the transition of undocumented patients from emergency to scheduled 
hemodialysis', Kidney International , 99(1):198207.

Cohen, D., et al., 2019, Use of the KDQOL-36 ${ }^{\mathrm{TM}}$ for assessment of health-related quality of life among dialysis patients in the United States, $B M C$ Nephrology (2019) 20:112.

Eğlence, R., Karataş, N., \& Taşci, S., 2013, 'The effect of acupressure on the level of fatigue in hemodialysis patients', Altern Ther Health Med. Nov-Dec;19(6):23-31.

Georgios, T., et al, 2015, 'Assessment of Quality of Life and Fatigue among Haemodialysis Patients', American Journal of Nursing Science, Special Issue: Mental Health Care: Aspects, Challenges and Perspectives, Vol. 4, No. 2-1, 2015, pp. 66-73.

Indonesian Renal Resgistry, 2018, $11^{\text {th }}$ Report Of Indonesian Renal Registry. https:/www. indonesianrenalregistry.org/data/IRR\%202018. pdf diakses pada tanggal 26 Oktober 2020

Işık Ulusoy, S., \& Kal, Ö, 2020, 'Relationship Among Coping Strategies, Quality of Life, and Anxiety and Depressive Disorders in Hemodialysis Patients. Therapeutic apheresis and dialysis : official peer-reviewed journal of the International Society for Apheresis', the Japanese Society for Dialysis Therapy, 24(2), 189-196.

Jacobson, et al, 2019, 'Patient Perspectives on the Meaning and Impact of Fatigue in Hemodialysis: A Systematic Review and Thematic Analysis of Qualitative Studies', American Journal of Kidney Disease, Vol 74, Issue 2, P179-192.

Jhamb, M., Pike, F., Ramer, S., Argyropoulos, C., Steel, J., Dew, M. A., ...Unruh, M, 2011, 'Impact of fatigue on outcomes in the hemodialysis (HEMO) study', American Journal of Nephrology, 33(6), 515-523.

Natashia, D., Irawati, D., \& Hidayat, F., 2020, Fatigue Dan Kualitas Hidup Pada Pasien Gagal Ginjal Kronis Dengan Terapi Hemodialisa, Jurnal Keperawatan Muhammadiyah 5 (2) 2020.

Smart N, \& Steele M, 2011, 'Exercise training in haemodialysis patients: a systematic review and meta-analysis', Nephrology (Carlton), 2011 Sep;16(7):626-32.

Supriyadi, R., Rakhima, F., Gondodiputro, R., \& Darmawan, G., 2019, 'Validity and Reliability of the Indonesian Version of Kidney Disease Quality of Life (KDQOL-36) Questionnaire in Hemodialysis Patients at Hasan Sadikin Hospital,
Bandung, Indonesia', Indones J Intern Med, Vol 51, Number 4.

Toruan, E., 2019, Pengaruh Lotion Oat Terhadap Sensasi Gatal Pada Pasien Hemodialisa yang Mengalami Pruritus di RS Kota Medan, Tesis Program Studi Ilmu Keperawatan Fakultas Keperawatan Universitas Sumatera Utara.

Yang, P. C., \& Lu, Y. Y, 2017, 'Predictors of fatigue among female patients on hemodialysis', Nephrology Nursing Journal, 44(6), 533-539.

Yu, H. D., \& Petrini, M. A, 2010, 'The HRQoL of Chinese patients undergoing haemodialysis', Journal of Clinical Nursing, 19(5-6), 658-665. 